\title{
From the Archives
}

Editors' Note: Reprints of old essays will be published in some issues to make them accessible to a new generation and to track the historical development of some ideas.

The essays below are from ODU: Journal of Yoruba and Related Studies, January, 1955, No. 1.

\section{Yoruba Influences In Brazil}

Pierre Verger

Slave-trading brought Africans from many different regions to the Americas. The interplay of commercial exchange, however, helped towards a re-grouping of the new arrivals into their original nationalities. The slave-traders had regular sources of supply in certain regions of Africa and a corresponding clientele assured in the ports of the Americas. Trade between Bahia (Salvador) in Brazil on the one hand and Lagos on the Gulf of Benin on the other was particularly active. Boats journeyed direct between these two ports because in Bahia there was a ready supply of goods greatly in demand on the Coast: tobacco, cachaça (rum), and Carne de Sertaon (jackbeef).

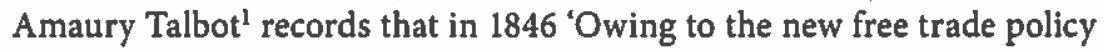
and the Sugar Act, the slave-grown sugars of Brazil and Cuba flooded the British markets, and in consequence the slave-traffic received a great stimulus', which took a large number of captive Yorubas to Brazil and Cuba.

Carlos $\mathrm{Ott}^{2}$ shows, from the statistics of the ethnical origin of slaves resident in Bahia, how real this Nago predominance was. (Nago is the name given in Brazil to the Yorubas.)

A re-distribution of the Africans into 'nations', based on the deeds of purchase and the sale of slaves between 1838 and 1860, shown in the municipal slaves of the town of Salvador (Bahia), gives the following figures: Nago 2,049; Djedje 286; Mina 117; Calabar 39; Benin 27 and Cache 1; (that is to say, 3,060 of Sudanese origin): Angola 267; Cabinda 65; Congo 48; Benguela 29; Gaboon 5; Cassanje 4 and Mozambique 42; (460 of Bantu origin).

1. The Peoples of Southern Nigeria. Amaury Talbot. London, Oxford University Press, 1926 (Vol. I, p. 49.)

2. O Negro Bahiano. Memoire de l'I.F.A.N. No. 27. Les Afro-Americains, Dakar 1953. (p. 147.) 
'We have then' he says 'on the one hand 3,060 Sudanese slaves, and on the other 460 Bantus. It was they who stamped the final African traits on the formation of the new culture of Bahia. One might have expected the completely pre-dominant numerical percentage of the Nagos to exercise a stronger cultural influence.

On their arrival, Africans were all baptized, but they remained attached to the gods of Africa and continued to worship them faithfully. The ceremonial ritual of the Nagos (and, to a lesser extent, that of the Djedjes) ${ }^{3}$ is in fact the one which has best preserved its African character in Bahia, and has most strongly influenced those of the other 'Nations'.

The last African slaves arrived in Bahia about ninety years ago. ${ }^{4}$ Some liberated ones returned to form a little colony with Brazilian ways and customs, but not all of them settled down again in their home countries. There is no lack of instances of freed slaves returning to Africa only to go back again to Brazil after several years, with not only wives and children but also their own domestic slaves, all of them remaining attached to their gods.

A very interesting phenomenon (already recorded by William Bascom ${ }^{5}$ with reference to Cuba) occurred in Brazil. This was an Afro-Catholic syncretism. Each Orisha was assimilated to a saint or a virgin of the Catholic religion. Originally this syncretism was merely a camouflage to disguise the cult of the Orishas, since formally the Catholic faith was authorized in Brazil.

On Sundays the captives were encouraged to group themselves into 'nations' and to organize 'Batuques' and listen to the playing of their drums. In the eyes of the government these meetings had the advantage of maintaining the Africans' consciousness of their origins, their feelings of pride in their own 'nation' and of scorn for others. Dividing them in this way made them easier to control and lessened the fear of any uprisings or revolutions. But the most obvious result of this institution of 'Batuques' was to maintain the cult of the African divinities. These meetings allowed them to indulge their ancient beliefs, indirectly. Their songs and dances, which in the eyes of their owners were mere amusements of nostalgic negroes, were in reality meetings where the gods of Africa were invoked.

When the master passed a group where they sang of the strength and avenging power of Shango the thunder god, or of Oya, god of the storms and the Niger, or of Qbatala, god of creation, and he asked the meaning of these songs, the reply of creation, and he asked the meaning of these songs, the reply was invariably 'Yoyo, we are worshipping in our fashion and in our

3. Name given to the Adjas (Fons) of Dahomey

4. (Slavery was abolished in Brazil in 1888. The Dahomeans ravaged Yoruba villages for slaves until 1892, when the French occupied Dahomey. -Ed.)

5. 'The Yoruba in Cuba.' William R. Bascom. Nigeria, 1951. (No. 37, p. 14.) 
tongue, Saint Jerome, Saint Barbara, or the Christ of Bomfim' (a Brazilian town). Thus under the shelter of an apparent syncretism, the old traditions have been maintained through the years. Everybody was content: the government to divide and rule and assure peace in the state, the slaves to sing and dance, the African gods to receive their praises and the masters to see such Catholic sentiments in their people.

Although it is now no longer necessary to disguise the object of gatherings to worship African gods, as the constitution in Brazil has authorized the practice of all religions, the habit has remained until the present day of giving the name of a Catholic saint to the temple of an African god. With time, an evolution has taken place, and the Afro-Catholic syncretism, which was originally nothing but a mask, has become more sincere. The new generations of 'Creoles' think that the 'Saint' and the 'Orisha' are one and the same thing, that the name alone has changed, but that, depending on the time and place, it should be addressed sometimes in Latin, sometimes in an African tongue. The peaceful nature of the relationship which has always existed between black and white in Brazil, and Bahia in particular, is reflected in this 'Africa in Brazil'. It is revealed as both kindly and cordial but as jealous of its secrets as Africa herself, preserving them with a remarkable tenacity.

The 'Candomble', the name given in Bahia to African ceremonies, represents to its disciples the traditions of ancestors who came from a country distant, inaccessible and almost fabulous; with traditions held on to tenaciously, which game them the strength to keep their identity in spite of the prejudice and the scorn in which their religions were held, and of the obligation to superimpose their masters' religion on their own.

In Brazil the 'Terreiros', or temples under Nago influence, consist of 'Peji' where are the altars of the divinities, and of the 'Barracon', a large room for public ceremonies, often adorned with statues and images of Catholic Saints. There are, besides, rooms and various buildings where the people belonging to the 'Terreiro' live when they come to fulfill their obligations to the Orishas. The responsibility for the cult rests on the 'Zelador' or 'Zeladora', also called the 'Pae or Mae of Santo' or even 'Babalorish' or 'Iyalorisha'. This office is most often held by a woman, particularly in the 'Terreiros' of the Ketu 'nation. ${ }^{\text {.6 }}$

The 'Pae or Mae of Santo' are assisted by 'Pequeno Pae or Mae', who replace them in time of need, by the 'Alagbe', responsible for the drums, by the 'Ashogun', who is in charge of the sacrifices, and by the 'Ogas', dignitaries chosen from among the associates of the Orishas. The latter are responsible

6. In Brazil the remembrance of the place of origin of the parents or grand-parents has remained very clear in the minds of African descendants, and there is often mention of Yoba (Yoruba), Oyo, Ijesha, Efon, Egba, Egabo, Tapa, Ogotun. 
for the protection of the 'Terreiro' and for its material welfare. Finally there are the "Filhos and Filhas of Santo' ('Iyaworisha" or 'Iyawo'), who are dedicated to the gods.

The latter are recruited in various ways. At the height of the dancing during a ceremony someone may fall into a violent trance and collapse, fainting, at the feet of a god. Another may have an unusual dream, find a strange object, suffer from an inexplicable disease, and have it revealed by an oracle that an Orisha has chosen him in this way to be an 'Iyawo'. These 'Iyaworishas', once chosen by the god, must be born into a new life, that of the sect. They go for a period of retreat and initiation, form a year to eighteen months.

Duties towards the gods consist of sacrifices of animals and private offerings of food in the 'Peji'. For the public ceremonies which follow afterwards, the "Barracon' is decorated with paper garlands in the colors of the god being honored that day. At the start of the orchestra, composed of three drums of different sizes and a double bell (Agogo), gives out a series of rhythmic appeals to the various gods, for each one has its own particular rhythm.

Shortly afterwards, 'Eshu Elegba', the messenger of the other gods, is despatched, and since he is, by nature, a troublemaker, he has first to be appeased in order to avoid troubles and difficulties during the course of the ceremony. The 'Iyawos' then sing and dance for each of the Orishas in turn. For three or four hours the disciples of these "gods-from-Africa" sing praises (in Yoruba) and appeals for their protection. Often they no longer know the meaning of the words which only a few sons of Africa still understand. All thse songs are the same as those of the Orishas of Nigeria. ${ }^{7}$ Sometimes the Orishas reply to these appeals, but they are only able to manifest themselves materially through their 'Iyawos', whom they send into a trance; taking possession of them and incorporating them into their own personalities. The 'Iyawos' in fact become Orishas.

The gods are greeted with cries and praises. Mounted on the 'Iyawos' they come and prostrate themselves before the orchestra, the 'Iyalorisha' and the 'Ogas' of the 'Terreiro', and are led off to the 'Peji' by the 'Ekedi', who are given the care of them.

The 'Iyawos' are dressed in clothes which are characteristic of the Orishas, adopting their arms or other symbolic objects. Once correctly dressed, all these gods return in a group to the 'Barracon'. They form a complete pantheon and dance one after the other in front of the assembled crowd. The principal Orishas who appear in this way are:

7. Research on these matters has been rendered possible, thanks to two study scholarships awarded by the Institut Francais d'Afrique Noire in 1949 and 1953. 
Eshu. Called familiarly 'god father'. He is the messenger of the other Orishas, evil and deliberately mischievous. Symbolized by a mound of earth, he is, erroneously, sycretised with the Devil for, properly treated, he works for food. His colors are red and black, his day Monday. He likes people to make him sacrifices of kids and black chickens for preference. If he shows himself, which is rare, the people cry 'Agongo Ogo Laroye'.

Ogun. God of iron, of the blacksmiths, warriors, farmers, and all those who work or use iron. But it is above all Ogun the Warrior who reveals himself. $\mathrm{He}$ is represented by 7-14, 16 or 2 iron instruments. Identified with Saint Anthony, his color is dark blue, his day Tuesday. He is associated with Eshu, whose brother he is, according to certain legends, as well as Oshosi. He dances armed with a sword; he mimics war and battle. He is saluted by cries of 'Ogun Ye'.

Oshosi, god of hunters, is represented by a bow and an iron arrow, and it identified with Saint George. His colour is green, his day Thursday. He dances with a bow and arrow in one hand and in 'irukere' in the other; he imitates hunting. He is saluted by cries of 'Oke'.

Logunede. Som of Oshosi and Oshun. This Orisha has the peculiarity of being a man for six months, living in the bush and eating game; and for six months he is a woman, living in the water and eating fish. He is saluted by cries of 'Logun'.

Omolu or Obaluwaiye. These are the names of Shapana, god of smallpox and contagious diseases, represented by a 'Shashara', a kind of straw wand covered with cowrie shells. Identified with Saint Lazarus or Saint Roques, his colours are red and black, his day Monday. His body is covered with straw, his face hidden; his dance symbolizes disease, suffering, itching, deformity, and feverish bodies. He is saluted by cries of 'Atolo'.

Nana Buruku. Mother of Omolu, the oldest of the water gods, syncretized with Saint Anne, her colours are white, red and blue, her day Tuesday. She dances with a dignity suited to a person of advanced age and is saluted by cries of 'Saluba'.

Oshumare. The rainbow. Represented by an iron snake, identified with Saint Bartholomew. His colours are green and yellow; his day Tuesday. He dances pointing to thesky and the earth. He is saluted by cries of 'Aoboboi'.

Shango. God of Thunder. Represented by the thunder stone, identified with Saint Jerome, his colours are white and red, his day Wednesday. Rams, chickens and tortoises are sacrificed to him. He dances with his 'Oshe', a double-axe, in his hand and with dignity, for he is considered in Brazil to be the ancestor of the Kings of the Yorubas. He is saluted with cries of 'Kawo Kabiyesi'.

Yansan or Oya. Wife of Shango; goddess of the river Niger, of the wind and the storms. Identified with Saint Barbara, her colour is red, her day is 
Wednesday. Goats are sacrificed to her, and she detests gourds. She dances with arms outstretched as if she dominated the elements and the souls of the dead, the 'Egun'. She is the only one of the Orishas who is able to confront them. She is saluted with cries of 'Epahei'.

Oshun. Second wife of Shango, goddess of fresh water. Identified with Our Lady of Candlemas, her day is Saturday. She dances with a fan in her hand, mimics a flirt who is going to bathe in the river, combs her hair, looks at herself in the glass, puts on bracelets and necklaces which she jingles with joy. She is saluted with cries of 'Ore Yeyeo'.

Yemaja. Goddess of the salt and fresh water. Identified with Our Lady of the Conception, her day is Saturday, her colour very transparent pale blue. She dances interpreting the movement of rough water. She is saluted with cries of 'Odoya'.

Finally, Oshala or Obatala, god of procreation, represented by ivory articles in a lead calabash. Identified with the Christ of Bomfim, his day is Friday, his colour white, he takes only white food without salt and without oil. In the form of Oshagiyan, he is a warrior dressed in white. In the form of Oshalufan, he dances bent like an old man, stumbling and leaning on a kind of crook. He is saluted with cries of 'Epa Babae Epa' and 'Esha Hee Eshe Hee'.

The relationship between the Orishas and the living is very familiar. The African gods retain a traditional longing to return to earth during festivals, to receive the greetings and offerings of men and reassure them, in return, of the protection, and to dance before them.

There are few countries where the descendants of Africans freed from slavery have retained, as in Bahia, this pride in their African origin, while feeling at the same time authentic and loyal Brazilians.

They get this feeling of pride from the real faith which they have kept in the power of the Orishas, who remain for them in times of stress a most steady support in face of anguish and humiliation, and in moments of joy give them an exultant realization of the spirit of their own race. It is important to emphasize this point and show how a people can adapt itself to a form of civilization which is more comfortable materially, without having to renounce completely the spiritual traditions of their ancestors.

Translated from the French by Elizabeth Bevan. 